\title{
Disturbance in uniformly ${ }^{13} \mathrm{C}$-labelled DHA metabolism in elderly human subjects carrying the apoE $\epsilon 4$ allele
}

\author{
R. Chouinard-Watkins ${ }^{1,2}$, C. Rioux-Perreault ${ }^{1}$, M. Fortier ${ }^{1}$, J. Tremblay-Mercier $^{1}$, Y. Zhang ${ }^{3}$, \\ P. Lawrence ${ }^{3}$, M. C. Vohl ${ }^{4}$, P. Perron ${ }^{5}$, D. Lorrain ${ }^{1,6}$, J. T. Brenna ${ }^{3}$, S. C. Cunnane B, $^{1,2,5}$ \\ and M. Plourde ${ }^{1,4,5 *}$ \\ ${ }^{1}$ Research Center on Aging, Health and Social Services Centre, University Institute of Geriatrics of Sherbrooke, \\ 1036 Belvédère Sud, Sherbrooke, QC, Canada J1H 4 C4 \\ ${ }^{2}$ Department of Physiology, Université de Sherbrooke, Sherbrooke, QC, Canada \\ ${ }^{3}$ Division of Nutritional Sciences, Cornell University, Ithaca, NY, USA \\ ${ }^{4}$ Institute of Nutraceuticals and Functional Foods and Department of Food Science and Nutrition, \\ Université Laval, Québec, QC, Canada \\ ${ }^{5}$ Department of Medecine, Université de Sherbrooke, Sherbrooke, QC, Canada \\ ${ }^{6}$ Départment of Psychology, Université de Sherbrooke, Sherbrooke, QC, Canada
}

(Submitted 28 September 2012 - Final revision received 19 March 2013 - Accepted 20 March 2013 - First published online 30 April 2013)

\section{Abstract}

Carrying the apoE $\epsilon 4$ allele (E4+) is the most important genetic risk for Alzheimer's disease. Unlike non-carriers (E4- ), E4+ seem not to be protected against Alzheimer's disease when consuming fish. We hypothesised that this may be linked to a disturbance in $n$ - 3 DHA metabolism in E4+. The aim of the present study was to evaluate $\left[{ }^{13} \mathrm{C}\right] \mathrm{DHA}$ metabolism over $28 \mathrm{~d}$ in E4+ $v$. E4-. A total of forty participants (twenty-six women and fourteen men) received a single oral dose of $40 \mathrm{mg}\left[{ }^{13} \mathrm{C}\right] \mathrm{DHA}$, and its metabolism was monitored in blood and breath over $28 \mathrm{~d}$. Of the participants, six were E4+ and thirty-four were E4-. In E4+, mean plasma $\left[{ }^{13} \mathrm{C}\right] \mathrm{DHA}$ was $31 \%$ lower than that in E4-, and cumulative $\beta$-oxidation of $\left[{ }^{13} \mathrm{C}\right] \mathrm{DHA}$ was higher than that in $\mathrm{E} 4-1-28 \mathrm{~d}$ post-dose $(P \leq 0 \cdot 05)$. A genotype $\times$ time interaction was detected for cumulative $\beta$-oxidation of $\left[{ }^{13} \mathrm{C}\right] \mathrm{DHA}(P \leq 0 \cdot 01)$. The whole-body half-life of $\left[{ }^{13} \mathrm{C}\right] \mathrm{DHA}$ was $77 \%$ lower in E4+ compared with E4- $(P \leq 0 \cdot 01)$. In E4+ and $\mathrm{E} 4-$, the percentage dose of $\left[{ }^{13} \mathrm{C}\right] \mathrm{DHA}$ recovered/h as ${ }^{13} \mathrm{CO} 2 \mathrm{correlated}$ with $\left[{ }^{13} \mathrm{C}\right] \mathrm{DHA}$ concentration in plasma, but the slope of linear regression was $117 \%$ steeper in $\mathrm{E} 4+$ compared with $\mathrm{E} 4-(P \leq 0 \cdot 05)$. These results indicate that DHA metabolism is disturbed in E4+, and may help explain why there is no association between DHA levels in plasma and cognition in $\mathrm{E} 4+$. However, whether $\mathrm{E} 4+$ disturbs the metabolism of ${ }^{13} \mathrm{C}$-labelled fatty acids other than DHA cannot be deduced from the present study.

\section{Key words: DHA: ApoE €4: Metabolism: $\beta$-Oxidation}

Regular consumption of fatty fish rich in $n-3$ PUFA such as DHA and EPA protects against CVD risk $^{(1,2)}$ and possibly against cognitive decline ${ }^{(3-5)}$. Several epidemiological studies have suggested that higher $n$ - 3 PUFA concentrations in plasma or erythrocytes are associated with a lower risk of ageing-associated cognitive decline ${ }^{(6-9)}$. However, carriers $(\mathrm{E} 4+)$ of the apoE $\epsilon 4$ allele, the most important genetic risk factor for Alzheimer's disease $^{(10)}$, seem not to be protected against cognitive decline by the consumption of fish ${ }^{(11)}$. Furthermore, higher erythrocyte $n-3$ PUFA are not associated with better cognitive function in $\mathrm{E} 4+{ }^{(12)}$.

DHA is a major structural component of brain membranes and is essential in neuronal development and repair, neurotransmission ${ }^{(13)}$, cell signalling and anti-inflammatory processes $^{(14,15)}$. Synthesis of EPA and DHA from $\alpha$-linolenic acid (ALA) is extremely limited in humans ${ }^{(16)}$, so it is advantageous that preformed EPA and DHA be present in the diet. The concentration of DHA in plasma usually follows a logarithmic distribution with dietary DHA intake ${ }^{(17,18)}$, but E4+ have a lower plasma response to $n-3$ PUFA supplementation compared with non-carriers of E4 $(\mathrm{E} 4-)^{(19)}$. Indeed, after receiving $3 \mathrm{~g} / \mathrm{d}$ of $\mathrm{EPA}+$ DHA for 6 weeks, DHA concentration in plasma TAG increased by $75 \%$ in $\mathrm{E} 4+$, whereas in $\mathrm{E} 4-$, the increase was $240 \%{ }^{(19)}$. Thus, E4+ appear to have altered DHA metabolism when given an $n$-3 PUFA supplement.

Abbreviations: ALA, $\alpha$-linolenic acid; $A P O E$, apoE gene; E4+, apoE $\epsilon 4$ allele carriers; E4-, apoE $\epsilon 4$ non-carriers.

*Corresponding author: Dr M. Plourde, fax +1 819829 7141, email melanie.plourde2@usherbrooke.ca 
There are two principal ways to assess DHA metabolism in human subjects: by perturbing plasma DHA with a DHA supplement or using isotopically labelled DHA. An oral dose of uniformly labelled carbon $13\left[{ }^{13} \mathrm{C}\right] \mathrm{DHA}^{(20)}$ is a precise and sensitive tool to evaluate the distribution of DHA in plasma and $\beta$-oxidation over time. $\left[{ }^{13} \mathrm{C}\right] \mathrm{DHA}$ metabolism in human subjects was first reported more than a decade ago ${ }^{(21-23)}$. In one study, the authors gave a single oral dose between 250 and $280 \mathrm{mg}\left[{ }^{13} \mathrm{C}\right] \mathrm{DHA}$ in the form of a TAG to three healthy men ${ }^{(22)} \cdot\left[{ }^{13} \mathrm{C}\right] \mathrm{DHA}$ levels reached a maximum $2 \mathrm{~h}$ post-dose in plasma TAG and the apparent retroconversion of $\left[{ }^{13} \mathrm{C}\right] \mathrm{DHA}$ to $\left[{ }^{13} \mathrm{C}\right] \mathrm{EPA}$ was estimated at $1.4 \%$ of the total plasma concentration of $\left[{ }^{13} \mathrm{C}\right] \mathrm{DHA}$. Recently, we gave $50 \mathrm{mg}\left[{ }^{13} \mathrm{C}\right] \mathrm{DHA}$ in the form of a methyl ester to six young and six elderly participants ${ }^{(24)}$ and showed that $4 \mathrm{~h}$ after the $\left[{ }^{13} \mathrm{C}\right] \mathrm{DHA}$ intake, the elderly had a fourfold higher $\left[{ }^{13} \mathrm{C}\right] \mathrm{DHA}$ concentration in plasma total lipids compared with the young participants ${ }^{(24)}$.

Using $\left[{ }^{13} \mathrm{C}\right] \mathrm{DHA}$, the objective of the present study was to evaluate whether DHA metabolism is different in $\mathrm{E} 4+v$. E4-. We report the distribution of $\left[{ }^{13} \mathrm{C}\right] \mathrm{DHA}$ in plasma total lipids, its apparent retroconversion to EPA detected in plasma total lipids, the $\beta$-oxidation of $\left[{ }^{13} \mathrm{C}\right] \mathrm{DHA}$ recovered in breath in the form of ${ }^{13} \mathrm{CO}_{2}$, and plasma and the wholebody half-life of $\left[{ }^{13} \mathrm{C}\right] \mathrm{DHA}$.

\section{Methods}

A total of forty participants over 50 years of age were recruited between January 2010 and April 2011 in the Eastern Townships of Quebec, Canada. All participants completed the thirty-item Montreal Cognitive Assessment test for baseline cognitive status ${ }^{(25)}$. Participants were all non-smokers, and free of dementia or diabetes. They did not have a diagnosis of cancer in the past 6 months, liver or renal disease, uncontrolled hyper- or hypothyroidism, autoimmune disorder, elevated markers of inflammation or low serum albumin. Anyone consuming $n$-3 PUFA capsules was excluded. The present study was conducted according to the guidelines laid down in the Declaration of Helsinki, and all procedures involving human participants were approved by the Human Ethics Research Committee of the Health and Social Sciences Center - Sherbrooke University Geriatrics Institute, which is the committee mandated to oversee human experimentation at our institution. Written informed consent was obtained from all participants. The study is registered at www.clinicaltrials.gov (NCT01577004).

\section{Tracer study design}

The $\left[{ }^{13} \mathrm{C}\right] \mathrm{DHA}$ used in the present study was uniformly labelled (>98\%) and of high chemical purity ( $99 \%$ pure). It was synthesised using micro-algae fed with $\left[{ }^{13} \mathrm{C}\right]$ glucose. Each $40 \mathrm{mg}$ dose of $\left[{ }^{13} \mathrm{C}\right] \mathrm{DHA}$ methyl ester was stored in an individual glass ampoule sealed under $\operatorname{Ar}^{(20)}$.

Participants arrived fasted on the morning of the metabolic study day. After collecting baseline blood and breath samples (see details below), the participants received a breakfast composed of two pieces of whole-wheat grain toast with peanut butter, one scrambled egg, one apple, $35 \mathrm{~g}$ mozzarella cheese and $250 \mathrm{ml}$ orange juice. The macronutrient composition of this $2805 \mathrm{~kJ}$ breakfast was as follows: $25.5 \mathrm{~g}$ fat, $78 \mathrm{~g}$ carbohydrate and $29 \mathrm{~g}$ protein. The $40 \mathrm{mg}$ dose of $\left[{ }^{13} \mathrm{C}\right] \mathrm{DHA}$ was added to a piece of toast. The breakfast was consumed by all participants within $15 \mathrm{~min}$. At $4 \mathrm{~h}$ after tracer consumption, the participants were given a lunch composed of lasagne with $200 \mathrm{ml}$ of V8 vegetable juice and a granola bar. The macronutrient composition of this $2093 \mathrm{~kJ}$ lunch was as follows: $15 \mathrm{~g}$ fat, $88 \mathrm{~g}$ carbohydrate and $23 \mathrm{~g}$ protein.

$\left[{ }^{13} \mathrm{C}\right]$ DHA metabolism was monitored in blood and breath samples collected at baseline $(0 \mathrm{~h})$ and at 1, 2, 4, 6 and $8 \mathrm{~h}$ post-dose. The participants returned to the metabolic unit 1 , 7, 14, 21 and $28 \mathrm{~d}$ post-dose for blood and breath sample collection. A $28 \mathrm{~d}$ follow-up was used since this is the typical amount of time needed for $\left[{ }^{13} \mathrm{C}\right] \mathrm{DHA}$ in plasma to return to baseline ${ }^{(24)}$. A catheter was installed in a forearm vein for the collection of blood samples on the first day; later, blood samples were collected using a $5 \mathrm{ml}$ syringe (Becton Dickinson) and transferred into $4 \mathrm{ml}$ EDTA tubes (Becton Dickinson). The tubes were centrifuged at $2300 \mathrm{~g}$ for $15 \mathrm{~min}$ at $4^{\circ} \mathrm{C}$, and plasma was stored in three $0.5 \mathrm{ml}$ Eppendorfs at $-80^{\circ} \mathrm{C}$ until further analyses.

To assess the appearance of ${ }^{13} \mathrm{CO}_{2}$ coming from the $\beta$-oxidation of $\left[{ }^{13} \mathrm{C}\right] \mathrm{DHA}$, participants breathed into a device consisting of a perforated plastic bag attached to a mouthpiece (EasySampler; QuinTron Instrument Company) to which an evacuated glass tube was inserted to collect a sample of the exhaled breath $^{(26,27)}$.

\section{Analytical methods}

Total lipids were extracted from $0.25 \mathrm{ml}$ of plasma using the method described by Folch et al. ${ }^{(28)}$. Heptadecanoate was added as an internal standard for quantification of fatty acids. To remove cholesterol, the total lipid extract was then saponified using $3 \mathrm{ml}$ of $1 \mathrm{M}-\mathrm{KOH}$-methanol and the mixture was heated at $90^{\circ} \mathrm{C}$ for $1 \mathrm{~h}$. Transmethylation of the resulting NEFA into fatty acid methyl esters was performed using $14 \%$ boron trifluoride-methanol (Sigma-Aldrich). Fatty acid methyl esters were analysed using a gas chromatograph (model 6890; Agilent) equipped with a $50 \mathrm{~m}$ BPX-70 fused capillary column (SGE). Injection and flame ionisation detection were performed at $250^{\circ} \mathrm{C}$ with the following oven temperature programme: $50^{\circ} \mathrm{C}$ for $2 \mathrm{~min}$, increased by $20^{\circ} \mathrm{C} / \mathrm{min}$ to $170^{\circ} \mathrm{C}$ for $15 \mathrm{~min}$ and finally increased by $5^{\circ} \mathrm{C} / \mathrm{min}$ to $210^{\circ} \mathrm{C}$ for $7 \mathrm{~min}$. He gas was used as a carrier and the inlet pressure was $233 \mathrm{kPa}$ at $50^{\circ} \mathrm{C}$. The identity of individual fatty acids was determined using standard mixtures of fatty acids (NuChek 68A, NuChek 411 and NuChek 455; NuChek Prep, Inc.) and a custom mixture of SFA.

$\left[{ }^{13} \mathrm{C}\right] \mathrm{DHA}$ enrichment analysis in plasma total lipids was performed using GC-combustion-isotope ratio MS, as described previously ${ }^{(29)} \cdot{ }^{13} \mathrm{C} /{ }^{12} \mathrm{C}$ post-dose was compared with baseline ${ }^{13} \mathrm{C} /{ }^{12} \mathrm{C}$ (pre-dose) to calculate the $\delta$ (per mil) values that were designated thereafter as atom per cent excess. Calculations of $\left[{ }^{13} \mathrm{C}\right] \mathrm{DHA}(\mathrm{nmol} / \mathrm{ml})$ and $\left[{ }^{13} \mathrm{C}\right] \mathrm{EPA}(\mathrm{pmol} / \mathrm{ml})$ from the atom 
per cent excess values were performed according to Brossard et al. $^{(22)}$.

Enrichment of ${ }^{13} \mathrm{C}$ in breath $\mathrm{CO}_{2}$ after $\left[{ }^{13} \mathrm{C}\right] \mathrm{DHA}$ consumption was analysed by isotope ratio MS (ABCA, Sercon Limited), as described previously ${ }^{(27)}$. He gas (Praxair) was used as a carrier and $5 \% \mathrm{CO}_{2} / \mathrm{N}_{2}$ as the reference gas. The percentage dose of $\left[{ }^{13} \mathrm{C}\right] \mathrm{DHA}$ recovered in breath as ${ }^{13} \mathrm{CO}_{2}$ was calculated as described previously ${ }^{(26)}$, except that basal metabolism was evaluated using indirect calorimetry (CCM/D; Medgraphics Corporation) to measure the volume of $\mathrm{CO}_{2}$ and $\mathrm{O}_{2}$ exhaled by the participants over $30 \mathrm{~min}^{(30)}$. Cumulative $\beta$-oxidation of $\left[{ }^{13} \mathrm{C}\right] \mathrm{DHA}$ was calculated from the AUC of the percentage dose recovered at each time point (GraphPad Prism 5 software; GraphPad Software, Inc.).

$\left[{ }^{13} \mathrm{C}\right] \mathrm{DHA}$ half-life in plasma was calculated using RxKinetics online software (RxKinetics; www.rxkinetics.com). The values of two E4- participants were excluded because $\left[{ }^{13} \mathrm{C}\right] \mathrm{DHA}$ concentrations in plasma were not available for time points 14,21 and $28 \mathrm{~d}$. $\left[{ }^{13} \mathrm{C}\right] \mathrm{DHA}$ half-life in the whole body was estimated for each participant using cumulative ${ }^{13} \mathrm{CO}_{2}$ data. For three $\mathrm{E} 4+$ and twenty-five $\mathrm{E} 4-$ not reaching a cumulative $\beta$-oxidation of $50 \% 28 \mathrm{~d}$ post-dose, it was assumed from the cumulative ${ }^{13} \mathrm{CO}_{2}$ data of the other participants that beyond $28 \mathrm{~d}$, the curve would be linear (see Fig. 1(d)). Therefore, using the cumulative ${ }^{13} \mathrm{CO}_{2}$ data at times 1, 7, 14, 21 and $28 \mathrm{~d}$ post-dose, a linear equation in the form of $y=m x+b$, where $m$ is the slope and $b$ is the $y$ value when $x=0$, was calculated for each participant to estimate the time needed $(x)$ to reach $50 \%(y)$ of cumulative $\beta$-oxidation of $\left[{ }^{13} \mathrm{C}\right] \mathrm{DHA}$ recovered as ${ }^{13} \mathrm{CO}_{2}$. As a result, five E4- were excluded because $\beta$-oxidation of $\left[{ }^{13} \mathrm{C}\right] \mathrm{DHA}$ recovered as ${ }^{13} \mathrm{CO}_{2}$ reached a plateau of $<50 \% 7 \mathrm{~d}$ post-dose, so it was not possible to estimate the whole-body $\left[{ }^{13} \mathrm{C}\right] \mathrm{DHA}$ half-life. Correlations between $\left[{ }^{13} \mathrm{C}\right] \mathrm{DHA}$ concentration in plasma and the percentage dose of $\left[{ }^{13} \mathrm{C}\right] \mathrm{DHA}$ recovered as breath ${ }^{13} \mathrm{CO}_{2}$ were performed using all time points for all participants ( $n 58$ for $\mathrm{E} 4+$ and $n 314$ for $\mathrm{E} 4-$ ). Baseline values of ${ }^{13} \mathrm{C}$ in plasma DHA and the percentage of ${ }^{13} \mathrm{C}$ in $\mathrm{CO}_{2}$ were removed before the correlations between $\left[{ }^{13} \mathrm{C}\right] \mathrm{DHA}$ concentration in plasma and the percentage dose of $\left[{ }^{13} \mathrm{C}\right] \mathrm{DHA}$ recovered as breath ${ }^{13} \mathrm{CO}_{2}$ since these values were standardised at zero in our calculations. The slopes of the linear regression between $\left[{ }^{13} \mathrm{C}\right] \mathrm{DHA}$ concentration in plasma and the percentage dose of $\left[{ }^{13} \mathrm{C}\right] \mathrm{DHA}$ recovered as breath ${ }^{13} \mathrm{CO}_{2}$ was calculated and compared between $\mathrm{E} 4+$ and E4- .

\section{ApoE genotyping}

DNA of the participants was extracted from $200 \mu$ l of whole blood (QIAmp DNA Blood Mini Kit; Qiagen). The DNA fragment containing the apoE gene $(A P O E)$ sequence was amplified by PCR (Perkin Elmer GeneAmp PCR System 2400; Perkin Elmer) using the oligonucleotide primers F6 (5'-TAAGCTTGGCACGGCTGTCCAAGGA-3') and F4 (5'-ACAGAATTCGCCCCGGCCTGGTACAC- $\left.3^{\prime}\right)$, as described previously ${ }^{(31)}$. After amplification, the DNA fragment was digested using Hha I (New England Biolabs Ltd) in order to reveal differential digestion patterns related to the $A P O E$ genotype. DNA fragments were then loaded on a $20 \%$ polyacrylamide gel for migration at $220 \mathrm{~V}$ for $3 \mathrm{~h}$ and the fragments were revealed using ethidium bromide ${ }^{(32)}$.
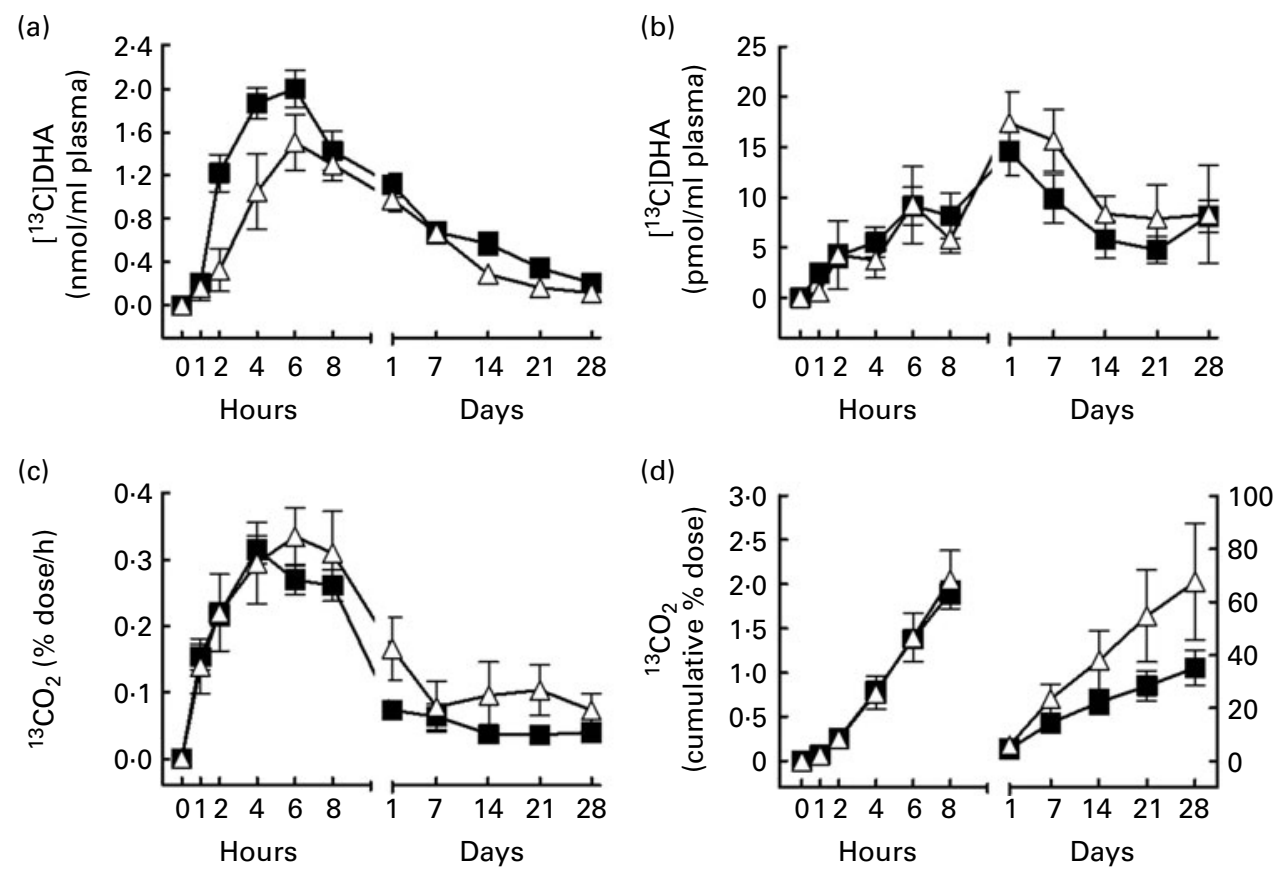

Fig. 1. $\left[{ }^{13} \mathrm{C}\right] \mathrm{DHA}$ metabolism over $28 \mathrm{~d}$ after an oral dose of $40 \mathrm{mg}\left[{ }^{13} \mathrm{C}\right] \mathrm{DHA}$ in apoE $\epsilon 4$ carriers $(\mathrm{E} 4+, \Delta, n 6)$ and non-carriers $(\mathrm{E} 4-$, $\mathbf{a}, n 34)$. (a) $\left[{ }^{13} \mathrm{C}\right] \mathrm{DHA}$ concentration $(\mathrm{nmol} / \mathrm{ml})$ in plasma total lipids, (b) $\left[{ }^{13} \mathrm{C}\right] \mathrm{DHA}$ apparent retroconversion into $\left[{ }^{13} \mathrm{C}\right] \mathrm{EPA}$ in plasma total lipids, (c) the percentage dose of $\left[{ }^{13} \mathrm{C}\right] \mathrm{DHA}$ recovered/h as ${ }^{13} \mathrm{CO}_{2}$ in breath and (d) the cumulative percentage dose of $\left[{ }^{13} \mathrm{C}\right] \mathrm{DHA}$ recovered as ${ }^{13} \mathrm{CO}_{2}$ over $28 \mathrm{~d}$ of follow-up. In (d), the left curves follow the left $y$-axis, whereas the right curves follow the right $y$-axis. The estimated slope of the right curve ( $m$ ) was 0.09 (SEM 0.03 ) in E4+ $v$. 0.05 (SEM 0.01 ) in E4- $(P=0.03)$. Values are means, with their standard errors represented by vertical bars. There were significant effects for $(a)$ genotype $(P=0.04)$ and $(d)$ the genotype $\times$ time interaction $(P=0.003)$. 


\section{Data expression and statistics}

Sample size was based on a calculation that the maximum concentration of $\left[{ }^{13} \mathrm{C}\right] \mathrm{DHA}$ in plasma total lipids that would be reached in the postprandial period would be $0.9 \mathrm{nmol} / \mathrm{ml}^{(24)}$. From our previous study ${ }^{(24)}$, we estimated that a twofold difference in plasma $\left[{ }^{13} \mathrm{C}\right] \mathrm{DHA}$ concentration would be observed between E4+ and E4- in the postprandial period ${ }^{(19)}$. Therefore, the sample size required to detect this difference using a $5 \%$ significance level and a power of $80 \%$ was six subjects per group ${ }^{(33)}$. We based our sample size calculation only on plasma $\left[{ }^{13} \mathrm{C}\right] \mathrm{DHA}$ concentration because DHA in plasma is one of the best documented biomarkers of the difference between E4+ and E4- (19). Moreover, since pre-screening for $\mathrm{E} 4+$ is not permitted at our institution, we therefore enrolled forty participants to recruit at least six E4+ on the assumption that $\mathrm{E} 4+$ frequency is approximately $15-25 \%^{(34,35)}$ in the general population, heterozygous and homozygous E4+ combined. Data are shown as means with their standard errors.

Statistics in Fig. 1 were performed using the PROC MIXED procedure implemented in SAS since some participants had missing data (SAS 9.2; SAS Institute) ${ }^{(36)}$. This procedure was used instead of a classical two-way ANOVA to optimise the use of all data over time and maintain statistical power. The PROC MIXED procedure allows testing for the effect of time as a repeated measure, genotype as a fixed factor (E4+ $v$. $\mathrm{E} 4-)$ and the interaction genotype $\times$ time. Student's $t$ tests were performed on Fig. 2, Table 1 and Table 2 to detect significant differences between E4+ and E4- (SPSS 17.0; SPSS, Inc.). The correlation coefficient $(R)$ of the correlations between plasma $\left[{ }^{13} \mathrm{C}\right] \mathrm{DHA}$ and $\left[{ }^{13} \mathrm{C}\right] \mathrm{DHA}$ recovered/h as breath ${ }^{13} \mathrm{CO}_{2}$ was performed using the bivariate correlation program in SPSS (Fig. 3). To account for potential confounding factors, correlation analyses were performed between $\left[{ }^{13} \mathrm{C}\right] \mathrm{DHA}$ recovered/h as breath ${ }^{13} \mathrm{CO}_{2}$ and baseline characteristics such as age, sex, cholesterol levels, glucose levels and medications. Statistically significant correlations were included in a multiple linear regression model. The slopes $(\beta)$ of the linear regression between plasma $\left[{ }^{13} \mathrm{C}\right] \mathrm{DHA}$ and $\left[{ }^{13} \mathrm{C}\right] \mathrm{DHA}$ recovered/h as ${ }^{13} \mathrm{CO}_{2}$ were compared between $\mathrm{E} 4+$ and E4- For cumulative $\beta$-oxidation of $\left[{ }^{13} \mathrm{C}\right] \mathrm{DHA}$ recovered as ${ }^{13} \mathrm{CO}_{2}$ between $\mathrm{E} 4+$ and $\mathrm{E} 4-$, a simple linear regression model was used to compare the slope $(m)$ between $1 \mathrm{~d}$ and $28 \mathrm{~d}$ post-dose. Statistical significance was set at $P \leq 0.05$.

\section{Results}

In the present study, six participants were E4+ (five E3/E4 and one E2/E4, two men and four women) and thirtyfour were E4- (twenty-eight E3/E3 and six E2/E3, twelve men and twenty-two women). In $\mathrm{E} 4+$, the mean age was 68.0 (SEM 3.3) years, whereas it was 72.4 (SEM 1.5) years in E4- (NS; Table 1). There was no difference in baseline characteristics between E4+ and E4- (Table 1) and between men and women (data not shown). The participants' score on the thirty-item Montreal Cognitive Assessment test was 26.1 (SEM 0.5) (maximum score of 30), indicating that they were cognitively healthy at baseline ${ }^{(25)}$. In $\mathrm{E} 4+$ at baseline, the mean plasma DHA concentration was 73 (SEM 9) $\mathrm{mg} / \mathrm{l}$, which was equivalent to 1.9 (SEM 0.4 ) \% of plasma total fatty acids, whereas in E4-, DHA concentration was 60 (SEM 4) $\mathrm{mg} / \mathrm{l}$, which was equivalent to 1.6 (SEM $0 \cdot 1$ ) \% of plasma total fatty acids (Table 2). There was no difference in fasting plasma fatty acid compositions between E4+ and E4- (Table 2).

\section{$\left[{ }^{13} \mathrm{C}\right] \mathrm{DHA}$ metabolism in apoE $\epsilon 4$ allele carriers v. apoE $\epsilon 4$ non-carriers}

The PROC MIXED procedure detected no genotype $\times$ time interaction with plasma $\left[{ }^{13} \mathrm{C}\right] \mathrm{DHA}$ (Fig. 1(a)). Nevertheless, a genotype effect was detected for plasma $\left[{ }^{13} \mathrm{C}\right] \mathrm{DHA}$, such that in $\mathrm{E} 4+,\left[{ }^{13} \mathrm{C}\right] \mathrm{DHA}$ in plasma total lipids from $1 \mathrm{~h}$ to $28 \mathrm{~d}$ post-dose was $31 \%$ lower compared with E4- (mean 0.66 $(\operatorname{SEM} 0 \cdot 14) \mathrm{nmol} / \mathrm{ml}$ in E $4+v .0 .96(\operatorname{sem} 0 \cdot 11) \mathrm{nmol} / \mathrm{ml}$ in E4-, $P=0.04$; Fig. 1(a)). In both groups, $\left[{ }^{13} \mathrm{C}\right] \mathrm{DHA}$ peaked in plasma total lipids $6 \mathrm{~h}$ after tracer intake; in $\mathrm{E} 4+$, the maximum value of $\left[{ }^{13} \mathrm{C}\right] \mathrm{DHA}$ was $1.5(\operatorname{sem} 0.3) \mathrm{nmol} / \mathrm{ml}$, whereas it was $2 \cdot 0(\operatorname{SEM} 0 \cdot 2) \mathrm{nmol} / \mathrm{ml}$ in E4- (NS; Fig. 1(a)).

The apparent retroconversion of $\left[{ }^{13} \mathrm{C}\right] \mathrm{DHA}$ into $\left[{ }^{13} \mathrm{C}\right] \mathrm{EPA}$ peaked $1 \mathrm{~d}$ post-dose, but was not different between $\mathrm{E} 4+$ and $\mathrm{E} 4-$ and no genotype $\times$ time interaction was detected for plasma $\left[{ }^{13} \mathrm{C}\right] \mathrm{EPA}$ concentration (Fig. 1(b)). In $\mathrm{E} 4+$, $\left[{ }^{13} \mathrm{C}\right] \mathrm{EPA}$ concentration in plasma total lipids reached a maximum of $17 \cdot 4$ (SEM $3 \cdot 1) \mathrm{pmol} / \mathrm{ml}$, representing $1.2 \%$ of the peak plasma $\left[{ }^{13} \mathrm{C}\right] \mathrm{DHA}$ concentration, whereas in $\mathrm{E} 4-$, $\left[{ }^{13} \mathrm{C}\right]$ EPA concentration in plasma total lipids reached a maximum of 14.4 (SEM 2.4$) \mathrm{pmol} / \mathrm{ml}$, representing $0.7 \%$ of the peak $\left[{ }^{13} \mathrm{C}\right]$ DHA concentration (NS; Fig. 1(b)).

The percentage dose of $\left[{ }^{13} \mathrm{C}\right] \mathrm{DHA}$ recovered/h as ${ }^{13} \mathrm{CO}_{2}$ did not differ at any time point between $\mathrm{E} 4+$ and $\mathrm{E} 4-$ over (a)

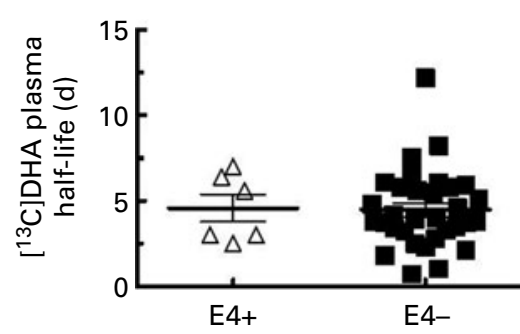

(b)

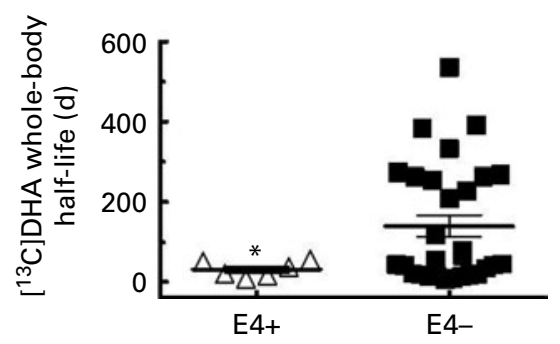

Fig. 2. $\left[{ }^{13} \mathrm{C}\right] \mathrm{DHA}$ half-life in (a) plasma and (b) in the whole body in apoE $\epsilon 4$ carriers (E4+, $\left.\Delta, n 6\right)$ and non-carriers (E4-, $\mathbf{\square}, n 32$ for (a) and $n 29$ for (b)). Values are means, with their standard errors represented by vertical bars. * Mean value was significantly different compared with $\mathrm{E} 4-(P \leq 0.05)$. 
Table 1. Baseline characteristics of apoE $\epsilon 4$ allele carriers (E4+) and apoE $\epsilon 4$ non-carriers ( $E 4-$ )

(Mean values with their standard errors)

\begin{tabular}{|c|c|c|c|c|c|}
\hline & \multicolumn{2}{|c|}{$\mathrm{E} 4+(n 6)$} & \multicolumn{2}{|c|}{$\mathrm{E} 4-(n 34)$} & \multirow[b]{2}{*}{$P$} \\
\hline & Mean & SEM & Mean & SEM & \\
\hline Age (years) & 68.0 & 3.3 & $72 \cdot 4$ & 1.5 & 0.35 \\
\hline \multicolumn{6}{|l|}{$\operatorname{Sex}(n)$} \\
\hline Male & \multirow{2}{*}{\multicolumn{2}{|c|}{2}} & \multicolumn{2}{|c|}{12} & \\
\hline Female & & 4 & \multicolumn{2}{|c|}{22} & \\
\hline BMI $\left(\mathrm{kg} / \mathrm{m}^{2}\right)$ & 29.3 & $2 \cdot 3$ & $27 \cdot 2$ & 0.7 & 0.57 \\
\hline $\mathrm{H} 1 \mathrm{Ac} \mathrm{Hb}(\%)$ & $6 \cdot 0$ & 0.2 & $5 \cdot 8$ & 0.1 & 0.21 \\
\hline Glucose (mmol/l) & $5 \cdot 1$ & 0.4 & 4.7 & $0 \cdot 1$ & 0.72 \\
\hline TSH (mIU/l) & 1.9 & 0.2 & 1.9 & 0.2 & 0.25 \\
\hline Total cholesterol $(\mathrm{mmol} / \mathrm{l})$ & 4.9 & 0.4 & 4.9 & 0.1 & 0.82 \\
\hline HDL-cholesterol (mmol/l) & $1 \cdot 3$ & 0.2 & 1.4 & 0.1 & 0.57 \\
\hline LDL-cholesterol (mmol/l) & $2 \cdot 6$ & 0.5 & $2 \cdot 8$ & 0.1 & 0.42 \\
\hline CRP (mg/l) & $3 \cdot 1$ & 1.6 & $3 \cdot 6$ & 0.7 & 0.40 \\
\hline TAG (mmol/l) & $2 \cdot 2$ & 0.8 & 1.4 & 0.1 & 0.90 \\
\hline MoCA test score* & $25 \cdot 3$ & $1 \cdot 1$ & $26 \cdot 2$ & 0.5 & 0.22 \\
\hline \multicolumn{6}{|l|}{ Medications $(n) \dagger$} \\
\hline Anti-hypertension agents $\ddagger$ & \multicolumn{2}{|c|}{3} & \multicolumn{2}{|c|}{15} & \\
\hline Statins & \multicolumn{2}{|c|}{3} & \multicolumn{2}{|c|}{14} & \\
\hline Acetylsalicylic acid & \multicolumn{2}{|c|}{1} & \multirow{2}{*}{\multicolumn{2}{|c|}{$\begin{array}{l}4 \\
6\end{array}$}} & \\
\hline Levothyroxine & \multirow{2}{*}{\multicolumn{2}{|c|}{$\begin{array}{l}0 \\
1\end{array}$}} & & & \\
\hline Biphosphonate & & & \multicolumn{2}{|c|}{7} & \\
\hline
\end{tabular}

TSH, thyroid-stimulating hormone; CRP, C-reactive protein; MoCA, Montreal Cognitive Assessment.

* Score out of a maximum of 30

†The number of subjects in each group receiving each medication.

¥ Anti-hypertensive agents include angiotensin-converting enzyme inhibitors, angiotensin receptor antagonists, $\beta$-blockers, $\mathrm{Ca}$ channel blockers and diuretics.

the $28 \mathrm{~d}$ of the study (Fig. 1(c)). On the other hand, a genotype $\times$ time interaction was detected with regard to cumulative $\beta$-oxidation of $\left[{ }^{13} \mathrm{C}\right] \mathrm{DHA}$ recovered as ${ }^{13} \mathrm{CO}_{2}$ $(P=0.003$; Fig. 1(d)). Moreover, in E4+, the slope of the cumulative ${ }^{13} \mathrm{CO}_{2}$ line $(m)$ between 1 and $28 \mathrm{~d}$ post-dose was $80 \%$ steeper than in E4- $(m=0.09$ (SEM 0.03) in E4+v. $m=0.05$ (SEM 0.01) in E4-, $P=0.03$; Fig. $1(\mathrm{~d})$ ). In $\mathrm{E} 4+$, cumulative $\beta$ oxidation of $\left[{ }^{13} \mathrm{C}\right] \mathrm{DHA}$ recovered as ${ }^{13} \mathrm{CO}_{2}$ reached a maximum of 68 (SEM 22) \% 28 d post-dose, whereas it reached 35 (SEM 7) \% in E4- (NS; Fig. 1(d)).
The $\left[{ }^{13} \mathrm{C}\right]$ DHA half-life in plasma was $4.6($ SEM $0 \cdot 8) \mathrm{d}$ in E4+ and 4.5 (SEM 0.4) d in E4- (NS; Fig. 2(a)). The whole-body $\left[{ }^{13} \mathrm{C}\right] \mathrm{DHA}$ half-life was heterogeneous and was $77 \%$ lower in E4+ compared with E4- (32 (SEM 8) d in E4+v. 140 (SEM 28) $\mathrm{d}$ in $\mathrm{E} 4-, P=0.001$; Fig. 2(b)). In two E4+, the mean whole-body $\left[{ }^{13} \mathrm{C}\right] \mathrm{DHA}$ half-life was $53 \mathrm{~d}$, whereas in four other carriers, it was $21 \mathrm{~d}$ (Fig. 2(b)). In eleven E4-, the whole-body $\left[{ }^{13} \mathrm{C}\right] \mathrm{DHA}$ half-life was $>200 \mathrm{~d}$, whereas in fourteen other E4-, it was $<50 \mathrm{~d}$ and in four E4-, it was between 50 and $200 \mathrm{~d}$ (Fig. 2(b)).

\section{Correlation between $\left[{ }^{13} \mathrm{C}\right] \mathrm{DHA}$ concentration in plasma and the percentage dose of $\left[{ }^{13} \mathrm{C}\right] \mathrm{DHA}$ recovered/h as ${ }^{13} \mathrm{CO}_{2}$}

In $\mathrm{E} 4+$ and $\mathrm{E} 4-$, the percentage dose of $\left[{ }^{13} \mathrm{C}\right] \mathrm{DHA}$ recovered/h as ${ }^{13} \mathrm{CO}_{2}$ correlated positively with $\left[{ }^{13} \mathrm{C}\right] \mathrm{DHA}$ concentration in plasma ( $R 0.56$ in E4+ and $R 0.39$ in $\mathrm{E} 4-, P<0.001$ for both; Fig. 3). The percentage dose of $\left[{ }^{13} \mathrm{C}\right] \mathrm{DHA}$ recovered/h as ${ }^{13} \mathrm{CO}_{2}$ also correlated with the levels of LDL-cholesterol and was associated with the use of a statin, so these potential confounding factors were included in the multivariate linear regression model. There was a positive interaction between genotype and linear regression of the percentage dose of $\left[{ }^{13} \mathrm{C}\right] \mathrm{DHA}$ recovered/h as ${ }^{13} \mathrm{CO}_{2}(y)$ with $\left[{ }^{13} \mathrm{C}\right] \mathrm{DHA}$ concentration in plasma $(x)$, and this interaction remained significant when accounting for confounding factors $(P<0 \cdot 001$; Fig. 3). The slope of the linear regression $(\beta)$ was $117 \%$ steeper in $\mathrm{E} 4+$ compared with $\mathrm{E} 4-(\beta=0.13(\operatorname{sem} 0.03)$ in $\mathrm{E} 4+v$. $\beta=0.06$ (sem 0.01) in E4-, $P<0.001$ ).

\section{Discussion}

These results demonstrate that $\left[{ }^{13} \mathrm{C}\right] \mathrm{DHA}$ metabolism is disturbed in $\mathrm{E} 4+$ compared with $\mathrm{E} 4-$ since $\mathrm{E} 4+$ had a $31 \%$ lower mean concentration of $\left[{ }^{13} \mathrm{C}\right] \mathrm{DHA}$ in plasma total lipids over time, but increased $\beta$-oxidation between 1 and $28 \mathrm{~d}$ post-dose. This difference may be due, at least in part, to the key role of

Table 2. Fatty acid concentration $(\mathrm{mg} / \mathrm{l})$ and percentage in plasma total lipids of apoE $\epsilon 4$ allele carriers $(\mathrm{E} 4+)(n 6)$ and apoE $\epsilon 4$ non-carriers (E4-) ( $n$ 34) at baseline

(Mean values with their standard errors)

\begin{tabular}{|c|c|c|c|c|c|c|c|c|c|c|}
\hline \multirow[b]{3}{*}{ Fatty acids } & \multicolumn{4}{|c|}{ Concentrations (mg/l) } & \multicolumn{5}{|c|}{ Relative percentage (\%) } & \multirow[b]{3}{*}{$P$} \\
\hline & \multicolumn{2}{|c|}{ E4+ } & \multicolumn{2}{|c|}{$\mathrm{E} 4-$} & \multirow[b]{2}{*}{$P$} & \multicolumn{2}{|c|}{$\mathrm{E} 4+$} & \multicolumn{2}{|c|}{ E4- } & \\
\hline & Mean & SEM & Mean & SEM & & Mean & SEM & Mean & SEM & \\
\hline $14: 0$ & $45 \cdot 0$ & $9 \cdot 0$ & $41 \cdot 0$ & $4 \cdot 0$ & 0.71 & $1 \cdot 0$ & $0 \cdot 2$ & $1 \cdot 1$ & 0.1 & 0.72 \\
\hline $16: 0$ & $1025 \cdot 0$ & $167 \cdot 0$ & $833 \cdot 0$ & 38.0 & 0.31 & $23 \cdot 0$ & $1 \cdot 3$ & $22 \cdot 5$ & 0.4 & 0.67 \\
\hline $16: 1 n-7$ & $123 \cdot 0$ & $37 \cdot 0$ & $95 \cdot 0$ & $8 \cdot 0$ & 0.48 & $2 \cdot 6$ & 0.5 & $2 \cdot 5$ & 0.2 & 0.89 \\
\hline 18: 0 & $286 \cdot 0$ & $34 \cdot 0$ & $246 \cdot 0$ & $8 \cdot 0$ & 0.30 & $6 \cdot 6$ & 0.3 & $6 \cdot 8$ & 0.2 & 0.62 \\
\hline $18: 1 n-9$ & $1130 \cdot 0$ & $231 \cdot 0$ & $824 \cdot 0$ & $41 \cdot 0$ & 0.25 & $24 \cdot 8$ & $2 \cdot 4$ & $22 \cdot 2$ & 0.4 & 0.33 \\
\hline $18: 1 n-7$ & 84.0 & $19 \cdot 0$ & $61 \cdot 0$ & 3.0 & 0.30 & $1 \cdot 8$ & 0.2 & 1.6 & 0.1 & 0.44 \\
\hline $18: 2 n-6$ & $1113 \cdot 0$ & $43 \cdot 0$ & $1081 \cdot 0$ & 52.0 & 0.80 & $27 \cdot 4$ & $3 \cdot 2$ & 29.5 & 0.9 & 0.54 \\
\hline $20: 3 n-6$ & $64 \cdot 0$ & $11 \cdot 0$ & $54 \cdot 0$ & 3.0 & 0.46 & $1 \cdot 4$ & 0.1 & 1.5 & 0.1 & 0.53 \\
\hline $20: 4 n-6$ & $282 \cdot 0$ & 21.0 & $254 \cdot 0$ & $13 \cdot 0$ & 0.40 & $6 \cdot 8$ & 0.7 & 6.9 & 0.2 & 0.82 \\
\hline $18: 3 n-3$ & $36 \cdot 0$ & 4.0 & 34.0 & 3.0 & 0.74 & 0.9 & 0.1 & 0.9 & 0.1 & 0.75 \\
\hline $20: 5 n-3$ & $36 \cdot 0$ & $6 \cdot 0$ & 35.0 & 3.0 & 0.94 & 0.9 & 0.2 & 1.0 & 0.1 & 0.76 \\
\hline $22: 5 n-3$ & $20 \cdot 0$ & $2 \cdot 0$ & $21 \cdot 0$ & 1.0 & 0.77 & 0.5 & 0.1 & 0.6 & 0.1 & 0.27 \\
\hline $22: 6 n-3$ & 73.0 & $9 \cdot 0$ & $60 \cdot 0$ & $4 \cdot 0$ & 0.24 & 1.9 & 0.4 & 1.6 & 0.1 & 0.59 \\
\hline
\end{tabular}




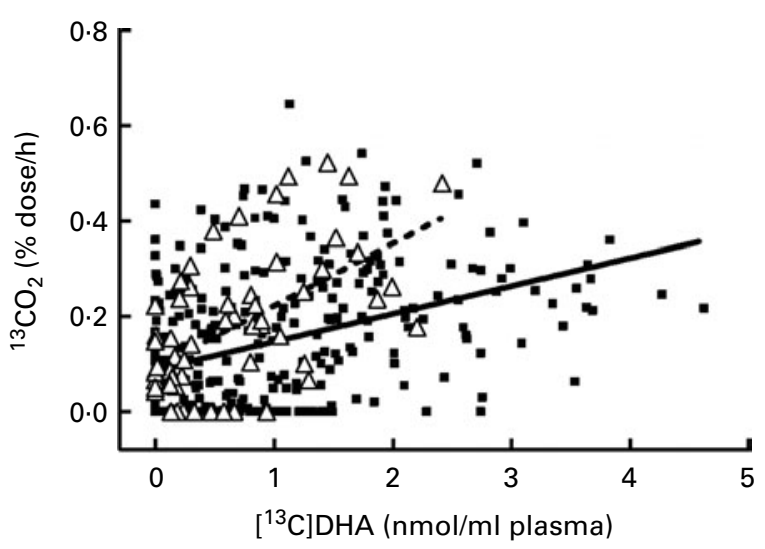

Fig. 3. Linear regression between $\left[{ }^{13} \mathrm{C}\right] \mathrm{DHA}$ concentration $(\mathrm{nmol} / \mathrm{ml})$ in plasma total lipids and the percentage dose of $\left[{ }^{13} \mathrm{C}\right] \mathrm{DHA}$ recovered/h as ${ }^{13} \mathrm{CO}_{2}$ in the breath of apoE $\epsilon 4$ carriers (E4+, $\left.\Delta,-\cdot \cdot, n 58, R 0.56\right)$ and non-carriers (E4-, $\mathbf{\square},-, n 314, R \quad 0.39$ ) over $28 \mathrm{~d}$ of follow-up. The linear regression model had a slope $(\beta)$ of 0.13 (SEM 0.03) in E4+ v. 0.06 (SEM 0.01) in E4- $(P<0.001)$.

apoE in postprandial plasma lipoprotein and lipid metabolism $^{(37)}$. ApoE has a high affinity for the LDL receptor that is involved in lipoprotein clearance from the plasma, notably chylomicron remnants and VLDL ${ }^{(38)}$. E4+ have a lower concentration of apoE protein in plasma ${ }^{(39)}$, but with proportionally more apoE in VLDL and less in HDL compared with homozygous carriers of apoE $\epsilon 3^{(40)}$. Therefore, clearance of VLDL in E4+ is potentially more rapid since this process relies partly on the binding of apoE protein with the LDL receptor ${ }^{(40)}$. Fatty acids travel in the blood mostly via lipoproteins, so a more rapid VLDL turnover potentially enhances $\left[{ }^{13} \mathrm{C}\right] \mathrm{DHA}$ clearance from the plasma, thereby supporting the present observation of lower plasma $\left[{ }^{13} \mathrm{C}\right] \mathrm{DHA}$ concentrations in E4+. Moreover, $\left[{ }^{13} \mathrm{C}\right] \mathrm{DHA}$ was ingested in the form of a methyl ester. Hence, it is possible that the observed differences in $\left[{ }^{13} \mathrm{C}\right] \mathrm{DHA}$ concentrations between E4+ and E4- might be partly due to a difference in the cleavage capacity of this form of DHA in E4+, although, to our knowledge, no study has evaluated this question.

Several studies have shown that E4+ have higher plasma TAG than $\mathrm{E} 4-$ in the postprandial state ${ }^{(41,42)}$, and that there is an age $\times A P O E$ genotype interaction with regard to TAG metabolism after an oral fat load ${ }^{(41,43)}$. Postprandially, E4+ over 50 years old had a higher AUC for plasma TAG concentrations compared with E4-, whereas this difference was absent between younger E4+ and E4- ${ }^{(41)}$. In the present study, all participants were aged $>50$ years old, so we would anticipate a higher DHA concentration in the postprandial state because of higher postprandial TAG levels in $\mathrm{E} 4+$. However, there was no difference between $\mathrm{E} 4+$ and E4- in total postprandial DHA expressed either in $\mathrm{mg} / \mathrm{l}$ or in relative percentage to other fatty acids. Nevertheless, TAG levels during the postprandial state were not evaluated in the present study, so we cannot confirm the results obtained by Carvalho-Wells et al. ${ }^{(41)}$ with regard to TAG concentrations in the postprandial state between E4+ and E4- .
We report here for the first time the $\beta$-oxidation of $\left[{ }^{13} \mathrm{C}\right] \mathrm{DHA}$ in $\mathrm{E} 4+$ and $\mathrm{E} 4-\mathrm{E} 4+$ had higher cumulative $\beta$-oxidation of $\left[{ }^{13} \mathrm{C}\right]$ DHA than E4- between 1 and $28 \mathrm{~d}$ post-dose (Fig. $1(\mathrm{~d})$ ). The estimated slope $(m)$ of the cumulative $\beta$-oxidation of $\left[{ }^{13} \mathrm{C}\right]$ DHA between 1 and $28 \mathrm{~d}$ post-dose was $80 \%$ steeper in E4+ than in E4- (Fig. 1(d)), suggesting a higher rate of the $\beta$-oxidation of $\left[{ }^{13} \mathrm{C}\right] \mathrm{DHA}$ in $\mathrm{E} 4+$ compared with $\mathrm{E} 4-$. This result could help explain the lower plasma $\left[{ }^{13} \mathrm{C}\right] \mathrm{DHA}$ in E4+ compared with E4-. The cumulative $\beta$-oxidation of $\left[{ }^{13} \mathrm{C}\right] \mathrm{DHA} 24 \mathrm{~h}$ post-dose was $6 \%$ in $\mathrm{E} 4+$ and $5 \%$ in $\mathrm{E} 4-$ (NS; Fig. 1(d)), which was nearly $75 \%$ lower compared with other common dietary fatty acids such as oleic acid (29\%), linoleic acid $(21 \%)$ or ALA $(31 \%)^{(27)}$. This suggests that in humans habitually consuming low levels of DHA, DHA is efficiently conserved, probably because of its structural importance in cell membranes ${ }^{(44)}$ and as a precursor to signalling molecules derived from DHA, notably resolvins and protectins ${ }^{(45)}$

Plasma $\left[{ }^{13} \mathrm{C}\right] \mathrm{DHA}$ correlated with the percentage dose of $\left[{ }^{13} \mathrm{C}\right] \mathrm{DHA}$ recovered/h as ${ }^{13} \mathrm{CO}_{2}$ in both $\mathrm{E} 4+$ and $\mathrm{E} 4-$, but the slope $(\beta)$ of this relationship was $117 \%$ steeper in $\mathrm{E} 4+$ than in E4- $(P<0 \cdot 001 ;$ Fig. 3$)$. Thus, for a given plasma concentration of $\left[{ }^{13} \mathrm{C}\right] \mathrm{DHA},{ }^{13} \mathrm{CO}_{2}$ was higher in $\mathrm{E} 4+$ than in $\mathrm{E} 4-$, showing more rapid $\beta$-oxidation of DHA. This difference in retention $v$. oxidation of DHA in $\mathrm{E} 4+$ is consistent with our previous report that the increase in plasma DHA after supplementing with EPA + DHA was lower in E4+ than in E4- (19). $\beta$-Oxidation of DHA is thought to be mainly conducted in peroxisomes $^{(46)}$, but the relative contribution of peroxisomal $v$. mitochondrial $\beta$-oxidation to the whole-body production of ${ }^{13} \mathrm{CO}_{2}$ from $\left[{ }^{13} \mathrm{C}\right] \mathrm{DHA}$ in humans is unknown. To the best of our knowledge, there are currently no available data supporting a potential role of APOE 4 polymorphism on the expression and/or activity of these peroxisomal enzymes $\beta$-oxidising DHA. A recent review by Lizard et al. ${ }^{(47)}$ has suggested the potential dysfunction of peroxisomal metabolism in patients with Alzheimer's disease. Since E4+ are more at risk to develop Alzheimer's disease, the present results showing more $\beta$-oxidation of $\left[{ }^{13} \mathrm{C}\right] \mathrm{DHA}$ needs further investigation since the $A P O E$ genotype may potentially affect Alzheimer's disease risk by affecting the molecular mechanism involved in fatty acid $\beta$-oxidation.

The present study is also the first to estimate plasma and whole-body half-lives of $\left[{ }^{13} \mathrm{C}\right] \mathrm{DHA}$. In previous studies, calculation of $\left[{ }^{13} \mathrm{C}\right] \mathrm{DHA}$ half-life was not possible since a follow-up of $<72 \mathrm{~h}$ did not provide enough time for plasma $\left[{ }^{13} \mathrm{C}\right] \mathrm{DHA}$ to return to baseline ${ }^{(22)}$. In our previous study ${ }^{(24)}, \beta$-oxidation of $\left[{ }^{13} \mathrm{C}\right]$ DHA was monitored over $7 \mathrm{~d}$ post-dose and gave a rough estimate of the $\left[{ }^{13} \mathrm{C}\right] \mathrm{DHA}$ whole-body half-life of about $10 \mathrm{~d}$, which is $66 \%$ less than our current estimate for E4+ and $90 \%$ less for E4- (Fig. 2). However, in the present study, $\beta$-oxidation of $\left[{ }^{13} \mathrm{C}\right] \mathrm{DHA}$ was followed over $28 \mathrm{~d}$ and the number of participants was higher than previously ${ }^{(22-24)}$, thus permitting a more accurate estimate of the whole-body half-life of $\left[{ }^{13} \mathrm{C}\right] \mathrm{DHA}$. We estimated that the whole-body half-life of $\left[{ }^{13} \mathrm{C}\right] \mathrm{DHA}$ was approximately $25 \mathrm{~d}$ more than its plasma half-life in E4+ and $>100 \mathrm{~d}$ more than its plasma half-life in E4-. Moreover, the whole-body half-life 
of $\left[{ }^{13} \mathrm{C}\right] \mathrm{DHA}$ was $77 \%$ lower in $\mathrm{E} 4+$ compared with E4-, corroborating higher $\beta$-oxidation of $\left[{ }^{13} \mathrm{C}\right] \mathrm{DHA}$ in $\mathrm{E} 4+$. Since the whole-body half-life values of $\left[{ }^{13} \mathrm{C}\right] \mathrm{DHA}$ were highly heterogeneous in the $\mathrm{E} 4-$ group, we investigated potential factors besides the $A P O E$ genotype that could be associated with a higher or lower whole-body half-life. No association was found between the whole-body half-life of $\left[{ }^{13} \mathrm{C}\right] \mathrm{DHA}$ and age, sex, baseline TAG levels, BMI, baseline DHA or EPA status and medications (data not shown).

The apparent retroconversion of $\left[{ }^{13} \mathrm{C}\right] \mathrm{DHA}$ into $\left[{ }^{13} \mathrm{C}\right] \mathrm{EPA}$ was $1 \cdot 2 \%$, which is similar to the level reported previously ${ }^{(22,24)}$. These results suggest that most of the $\left[{ }^{13} \mathrm{C}\right] \mathrm{DHA}$ remain in its native form in human subjects, whereas $\mathrm{E} 4+$ tend to have an overall higher $\beta$-oxidation of $\left[{ }^{13} \mathrm{C}\right] \mathrm{DHA}$ without producing more $\left[{ }^{13} \mathrm{C}\right]$ EPA compared with E4-

A potential confounding factor worth considering in the present study was whether sex disturbed DHA metabolism, as suggested by other studies ${ }^{(48-52)}$, since the results presented here involved men and women pooled together. Previous studies have shown that women tend to have higher DHA and EPA in plasma total lipids compared with men ${ }^{(48)}$, and this is potentially because of a higher conversion of ALA to EPA and DHA in women ${ }^{(49,51,53)}$ compared with men ${ }^{(54)}$. Moreover, using $\left[{ }^{13} \mathrm{C}\right] \mathrm{ALA}$, a study has reported higher $\beta$-oxidation in men compared with women, which was associated with higher ${ }^{13} \mathrm{C}$ enrichment in saturated acids and monounsaturated acids, suggesting a preferential pathway towards ALA degradation in men ${ }^{(52)}$. These sex-specific differences in $n-3$ PUFA metabolism seem to be in part explained by higher estrogens in pre-menopausal women ${ }^{(50)}$. In the present study, there was no difference in plasma $\left[{ }^{13} \mathrm{C}\right] \mathrm{DHA}$, plasma DHA or $\left[{ }^{13} \mathrm{C}\right] \mathrm{DHA}$ half-lives in the whole body or plasma between men and women (data not shown). This is probably because our participants were approximately 71 years old and all the women were postmenopausal. The drop in estrogen levels following menopause ${ }^{(55)}$ probably contributed to the lack of sex-specific differences in $\left[{ }^{13} \mathrm{C}\right] \mathrm{DHA}$ metabolism in the present study.

The present study had limitations. The number of E4+ was small when compared with E4-, but baseline characteristics were similar between the two groups (Table 1). Moreover, sample size calculation indicated that six participants should be enough to detect a significant difference in $\left[{ }^{13} \mathrm{C}\right] \mathrm{DHA}$ metabolism. Pre-screening for E4+ is not permitted at our institution, so the only alternative for recruiting $\mathrm{E} 4+$ participants is to run the trial and perform $A P O E$ genotyping afterwards. There was no difference in cholesterol levels between $\mathrm{E} 4+$ and $\mathrm{E} 4-$, even though other studies have suggested otherwise ${ }^{(56-58)}$, but our participants were elderly and three E4+ and fourteen E4- were on statins during the study. No difference in $\left[{ }^{13} \mathrm{C}\right] \mathrm{DHA}$ appearance in plasma and $\beta$-oxidation was observed when comparing the participants taking statins or not (data not shown). Another limitation of the present study was that $\left[{ }^{13} \mathrm{C}\right] \mathrm{DHA}$ was the only fatty acid tracer used to follow precisely its metabolism. Hence, whether E4+ disturbs the metabolism of fatty acids other than DHA cannot be deduced from the present study and will need further work with ${ }^{13} \mathrm{C}$-labelled fatty acids other than DHA.

\section{Conclusion}

Compared with E4-, E4+ had lower mean plasma $\left[{ }^{13} \mathrm{C}\right] \mathrm{DHA}$ between $1 \mathrm{~h}$ and $28 \mathrm{~d}$ post-dose, whereas $\beta$-oxidation of $\left[{ }^{13} \mathrm{C}\right] \mathrm{DHA}$ was higher between 1 and $28 \mathrm{~d}$ post-dose. For a similar level of $\left[{ }^{13} \mathrm{C}\right] \mathrm{DHA}$ in plasma, E4+ had higher ${ }^{13} \mathrm{CO}_{2}$ in breath and a lower whole-body half-life of $\left[{ }^{13} \mathrm{C}\right] \mathrm{DHA}$ compared with E4-, suggesting higher $\left[{ }^{13} \mathrm{C}\right] \mathrm{DHA}$ catabolism in $\mathrm{E} 4+$. Nevertheless, plasma $\left[{ }^{13} \mathrm{C}\right] \mathrm{DHA}$ half-life was similar between E4+ and E4-. Therefore, there seems to be no clear relationship between plasma half-life and the kinetics of $\left[{ }^{13} \mathrm{C}\right] \mathrm{DHA}$ metabolism. Given that DHA is important for cardiovascular and brain health, disturbance in $\left[{ }^{13} \mathrm{C}\right] \mathrm{DHA}$ metabolism in $\mathrm{E} 4+$ may increase their vulnerability to cognitive decline or other diseases. These results may help explain why no association between plasma DHA and cognition has been observed in $\mathrm{E} 4+$. Further studies evaluating $\left[{ }^{13} \mathrm{C}\right] \mathrm{DHA}$ metabolism after a DHA supplement are needed to evaluate whether a high dose of EPA + DHA could return DHA homeostasis in E4+ towards normal.

\section{Acknowledgements}

The present study was supported by the Advanced Foods and Materials Network, Research Center on Aging, Fonds de la recherche en santé du Québec for a scholarship and a Junior 1 salary award to M. P., Natural Sciences and Engineering Research Council of Canada, a Canada Research Chair to S. C. C., a Canada Research Chair to M. C. V. on Genomics Applied to Nutrition and Health and the Canada Foundation for Innovation. Conrad Filteau, Martine Fisch and Christine Brodeur-Dubreuil provided excellent technical assistance. We thank Dr Anthony Windust (National Research Council, Ottawa) for synthesising the $\left[{ }^{13} \mathrm{C}\right] \mathrm{DHA}$.

The authors' contributions were as follows: M. P. and S. C. C. designed the study; R. C.-W. conducted the study; Y. Z., P. L. and J. T. B. conducted the ${ }^{13} \mathrm{C}$ analyses; R. C.-W. and J. T.-M. performed the lipid analysis; M. P., S. C. C., R. C.-W. and J. T. B. analysed the data; R. C.-W. performed the statistical analysis; P. P. and R. C.-W. recruited the participants; M. C. V. performed the $A P O E$ genotyping; D. L. performed the cognitive tests; R. C.-W. prepared the first draft of the manuscript. All authors contributed to the writing and reviewing of the paper, and read and approved the final version of the manuscript.

The authors report no conflict of interest.

\section{References}

1. Balk EM, Lichtenstein AH, Chung M, et al. (2006) Effects of omega-3 fatty acids on serum markers of cardiovascular disease risk: a systematic review. Atherosclerosis 189, 19-30.

2. Burillo E, Martin-Fuentes P, Mateo-Gallego R, et al. (2012) Omega-3 fatty acids and HDL. How do they work in the prevention of cardiovascular disease? Curr Vasc Pharmacol 10, 432-441.

3. Morris MC, Evans DA, Bienias JL, et al. (2003) Consumption of fish and $n-3$ fatty acids and risk of incident Alzheimer disease. Arch Neurol 60, 940-946. 
4. Cunnane SC, Plourde M, Pifferi F, et al. (2009) Fish, docosahexaenoic acid and Alzheimer's disease. Prog Lipid Res $\mathbf{4 8}$, 239-256

5. Fotuhi M, Mohassel P \& Yaffe K (2009) Fish consumption, long-chain omega-3 fatty acids and risk of cognitive decline or Alzheimer disease: a complex association. Nat Clin Pract Neurol 5, 140-152.

6. Beydoun MA, Kaufman JS, Satia JA, et al. (2007) Plasma n-3 fatty acids and the risk of cognitive decline in older adults: the Atherosclerosis Risk in Communities Study. Am J Clin Nutr 85, 1103-1111.

7. Heude B, Ducimetiere P \& Berr C (2003) Cognitive decline and fatty acid composition of erythrocyte membranes The EVA Study. Am J Clin Nutr 77, 803-808.

8. Schaeffer EL, Forlenza OV \& Gattaz WF (2009) Phospholipase $\mathrm{A}_{2}$ activation as a therapeutic approach for cognitive enhancement in early-stage Alzheimer disease. Psychopharmacology (Berl) 202, 37-51.

9. Samieri C, Feart C, Proust-Lima C, et al. (2011) $\omega-3$ Fatty acids and cognitive decline: modulation by ApoEepsilon 4 allele and depression. Neurobiol Aging 32, 2317.e13-2317.e22.

10. Corder EH, Saunders AM, Strittmatter WJ, et al. (1993) Gene dose of apolipoprotein E type 4 allele and the risk of Alzheimer's disease in late onset families. Science 261, 921-923.

11. Huang TL, Zandi PP, Tucker KL, et al. (2005) Benefits of fatty fish on dementia risk are stronger for those without APOE epsilon4. Neurology 65, 1409-1414.

12. Whalley LJ, Deary IJ, Starr JM, et al. (2008) n-3 Fatty acid erythrocyte membrane content, APOE varepsilon4, and cognitive variation: an observational follow-up study in late adulthood. Am J Clin Nutr 87, 449-454.

13. Horrocks LA \& Yeo YK (1999) Health benefits of docosahexaenoic acid (DHA). Pharmacol Res 40, 211-225.

14. Calon F, Lim GP, Yang F, et al. (2004) Docosahexaenoic acid protects from dendritic pathology in an Alzheimer's disease mouse model. Neuron 43, 633-645.

15. Bouwens M, van de Rest O, Dellschaft N, et al. (2009) Fish-oil supplementation induces antiinflammatory gene expression profiles in human blood mononuclear cells. Am J Clin Nutr 90, 415-424.

16. Plourde M \& Cunnane SC (2007) Extremely limited synthesis of long chain polyunsaturates in adults: implications for their dietary essentiality and use as supplements. Appl Physiol Nutr Metab 32, 619-634.

17. Castellano C, Chouinard-Watkins R, Brenna T, et al. (2011) Does aging change docosahexaenoic acid homeostasis? Oléagineux Corps Gras Lipides (OCL) 18, 175-180.

18. Cunnane SC, Chouinard-Watkins R, Castellano CA, et al. (2013) Docosahexaenoic acid homeostasis, brain aging and Alzheimer's disease: can we reconcile the evidence? Prostaglandins Leukot Essent Fatty Acids 88, 61-70.

19. Plourde M, Vohl MC, Vandal M, et al. (2009) Plasma $n-3$ fatty acid response to an $n-3$ fatty acid supplement is modulated by apoE epsilon 4 but not by the common PPAR-alpha L162 V polymorphism in men. BrJ Nutr 102, 1121-1124.

20. Le PM, Fraser C, Gardner G, et al. (2007) Biosynthetic production of universally (13)C-labelled polyunsaturated fatty acids as reference materials for natural health product research. Anal Bioanal Chem 389, 241-249.

21. Brenna JT (1997) Use of stable isotopes to study fatty acid and lipoprotein metabolism in man. Prostaglandins Leukot Essent Fatty Acids 57, 467-472.

22. Brossard N, Croset M, Pachiaudi C, et al. (1996) Retroconversion and metabolism of $\left[{ }^{13} \mathrm{C}\right] 22: 6 n-3$ in humans and rats after intake of a single dose of $\left[{ }^{13} \mathrm{C}\right] 22: 6 n$-3-triacylglycerols. Am J Clin Nutr 64, 577-586.

23. Lemaitre-Delaunay D, Pachiaudi C, Laville M, et al. (1999) Blood compartmental metabolism of docosahexaenoic acid (DHA) in humans after ingestion of a single dose of $\left[{ }^{13} \mathrm{C}\right] \mathrm{DHA}$ in phosphatidylcholine. J Lipid Res 40, 1867-1874.

24. Plourde M, Chouinard-Watkins R, Vandal M, et al. (2011) Plasma incorporation, apparent retroconversion and betaoxidation of ${ }^{13} \mathrm{C}$-docosahexaenoic acid in the elderly. Nutr Metab (Lond) 8, 5 .

25. Nasreddine ZS, Phillips NA, Bedirian V, et al. (2005) The Montreal Cognitive Assessment, MoCA: a brief screening tool for mild cognitive impairment. J Am Geriatr Soc 53, 695-699.

26. Freemantle E, Vandal M, Tremblay Mercier J, et al. (2009) Metabolic response to a ketogenic breakfast in the healthy elderly. J Nutr Health Aging 13, 293-298.

27. McCloy U, Ryan MA, Pencharz PB, et al. (2004) A comparison of the metabolism of eighteen-carbon ${ }^{13} \mathrm{C}$-unsaturated fatty acids in healthy women. J Lipid Res 45, 474-485.

28. Folch J, Lees M \& Sloane Stanley GH (1957) A simple method for the isolation and purification of total lipides from animal tissues. J Biol Chem 226, 497-509.

29. Goodman KJ \& Brenna JT (1992) High sensitivity tracer detection using high-precision gas chromatography-combustion isotope ratio mass spectrometry and highly enriched [U- ${ }^{13}$ C]-labeled precursors. Anal Chem 64, 1088-1095.

30. Choquette S, Chuin A, Lalancette DA, et al. (2009) Predicting energy expenditure in elders with the metabolic cost of activities. Med Sci Sports Exerc 41, 1915-1920.

31. Emi M, Wu LL, Robertson MA, et al. (1988) Genotyping and sequence analysis of apolipoprotein E isoforms. Genomics $\mathbf{3}$, 373-379.

32. Hixson JE \& Vernier DT (1990) Restriction isotyping of human apolipoprotein $\mathrm{E}$ by gene amplification and cleavage with HhaI. J Lipid Res 31, 545-548.

33. Cochran GWSWG (1980) Statistical Methods, 7th ed., pp. 507. Iowa State University, IA: Iowa State University Press.

34. Garenc C, Aubert S, Laroche J, et al. (2004) Population prevalence of APOE, APOC3 and PPAR-alpha mutations associated to hypertriglyceridemia in French Canadians. J Hum Genet 49, 691-700.

35. Bullido MJ, Artiga MJ, Recuero M, et al. (1998) A polymorphism in the regulatory region of APOE associated with risk for Alzheimer's dementia. Nat Genet 18, 69-71.

36. Littell RC, Henry PR \& Ammerman CB (1998) Statistical analysis of repeated measures data using SAS procedures. J Anim Sci 76, 1216-1231.

37. Hooijmans CR \& Kiliaan AJ (2008) Fatty acids, lipid metabolism and Alzheimer pathology. Eur J Pharmacol 585, 176-196.

38. Mahley RW \& Ji ZS (1999) Remnant lipoprotein metabolism: key pathways involving cell-surface heparan sulfate proteoglycans and apolipoprotein E. J Lipid Res 40, 1-16.

39. Bahri R, Esteban E, Moral P, et al. (2008) Apolipoprotein gene polymorphisms and plasma levels in healthy Tunisians and patients with coronary artery disease. Lipids Health Dis 7, 46

40. Gregg RE, Zech LA, Schaefer EJ, et al. (1986) Abnormal in vivo metabolism of apolipoprotein E4 in humans. J Clin Invest 78, 815-821.

41. Carvalho-Wells AL, Jackson KG, Gill R, et al. (2010) Interactions between age and apoE genotype on fasting and postprandial triglycerides levels. Atherosclerosis 212, 481-487.

42. Kobayashi J, Saito Y, Taira K, et al. (2001) Effect of apolipoprotein $\mathrm{E} 3 / 4$ phenotype on postprandial triglycerides and 
retinyl palmitate metabolism in plasma from hyperlipidemic subjects in Japan. Atherosclerosis 154, 539-546.

43. Reznik Y, Morello R, Pousse P, et al. (2002) The effect of age, body mass index, and fasting triglyceride level on postprandial lipemia is dependent on apolipoprotein E polymorphism in subjects with non-insulin-dependent diabetes mellitus. Metabolism 51, 1088-1092.

44. Litman BJ, Niu SL, Polozova A, et al. (2001) The role of docosahexaenoic acid containing phospholipids in modulating $G$ protein-coupled signaling pathways: visual transduction. J Mol Neurosci 16, 237-242, discussion 79-84.

45. Serhan CN, Clish CB, Brannon J, et al. (2000) Novel functional sets of lipid-derived mediators with antiinflammatory actions generated from omega-3 fatty acids via cyclooxygenase 2-nonsteroidal antiinflammatory drugs and transcellular processing. J Exp Med 192, 1197-1204.

46. Liang X, Zhu D \& Schulz H (1999) Delta3,5,7,Delta2,4, 6-trienoyl-CoA isomerase, a novel enzyme that functions in the beta-oxidation of polyunsaturated fatty acids with conjugated double bonds. J Biol Chem 274, 13830-13835.

47. Lizard G, Rouaud O, Demarquoy J, et al. (2012) Potential roles of peroxisomes in Alzheimer's disease and in dementia of the Alzheimer's type. J Alzheimers Dis 29, 241-254.

48. Bakewell L, Burdge GC \& Calder PC (2006) Polyunsaturated fatty acid concentrations in young men and women consuming their habitual diets. BrJ Nutr 96, 93-99.

49. Burdge G (2004) Alpha-linolenic acid metabolism in men and women: nutritional and biological implications. Curr Opin Clin Nutr Metab Care 7, 137-144.
50. Decsi $T$ \& Kennedy K (2011) Sex-specific differences in essential fatty acid metabolism. Am J Clin Nutr 94, Suppl. 6 , 1914S-1919S.

51. Burdge GC \& Calder PC (2005) Conversion of alphalinolenic acid to longer-chain polyunsaturated fatty acids in human adults. Reprod Nutr Dev 45, 581-597.

52. Burdge GC \& Wootton SA (2003) Conversion of alphalinolenic acid to palmitic, palmitoleic, stearic and oleic acids in men and women. Prostaglandins Leukot Essent Fatty Acids 69, 283-290.

53. Burdge GC \& Wootton SA (2002) Conversion of alphalinolenic acid to eicosapentaenoic, docosapentaenoic and docosahexaenoic acids in young women. Br J Nutr 88, $411-420$.

54. Burdge GC, Jones AE \& Wootton SA (2002) Eicosapentaenoic and docosapentaenoic acids are the principal products of alpha-linolenic acid metabolism in young men. Br J Nutr $\mathbf{8 8}, 355-363$.

55. Cauley JA, Gutai JP, Kuller LH, et al. (1989) The epidemiology of serum sex hormones in postmenopausal women. Am J Epidemiol 129, 1120-1131.

56. Garry PJ, Baumgartner RN, Brodie SG, et al. (1999) Estrogen replacement therapy, serum lipids, and polymorphism of the apolipoprotein E gene. Clin Chem 45, 1214-1223.

57. Wehr H, Parnowski T, Puzynski S, et al. (2000) Apolipoprotein E genotype and lipid and lipoprotein levels in dementia. Dement Geriatr Cogn Disord 11, 70-73.

58. Giltay EJ, van Reedt Dortland AK, Nissinen A, et al. (2009) Serum cholesterol, apolipoprotein E genotype and depressive symptoms in elderly European men: the FINE study. $J$ Affect Disord 115, 471-477. 